\title{
THEME, ATTRIBUTES AND VALUE OF A VISIT TO ZHOUZHUANG, CHINA
}

\section{Lihua Gao}

Noel Scott

Peiyi Ding

\begin{abstract}
A memorable experience is created by many attributes that come together to involve consumers. A destination theme connects attributes to facilitate tourist's involvement in an experience. Few studies have examined how destination attributes combine to express a theme and lead to value for a tourist. Zhouzhuang, a popular Chinese water town associated with the theme "escape to a simpler time", was selected to examine how this theme is evoked. Content analysis of 63 in-depth interviews indicates that tourists linked their experiences in Zhouzhuang together under one theme and four main types of attributes. These attributes were linked to different types of customer value.
\end{abstract}

Keywords: destination experience; attributes; theme; customer value

\section{INTRODUCTION}

Tourism is a quintessential experience economy offering (Morgan, Elbe, \& de Esteban Curiel, 2009) and indeed the essence of tourism is "the development and delivery of travel and visitation experiences” (Ritchie, Tung, \& Ritchie, 2011, p. 419). Tourism, hospitality and leisure researchers have long recognised the importance of experiences in attracting tourists; early researchers such as Clawson (1963) studied recreation experiences while Boorstin (1964) discussed the authenticity of tourism experiences. In the 1970s, authors such as MacCannell (1976), Dann (1977), and Cohen (1979) identified tourism as providing an experience and it remains a continuing theme in the literature today (Hosany \& Witham, 2010).

An experience is inclusive of, but distinct from the tangible goods and intangible services offered to a customer, because it is engaging and leads to a "memorable event" (Pine \& Gilmore, 1998, p. 98). An experience "derives from the interaction between the staged event ... and the individual's state of mind” (p. 103), and is a blend of many attributes that come together (Shaw \& Ivens, 2002) to involve consumers emotionally, physically, 
intellectually, and spiritually (Carbone, 1998; Oswald, Ram, \& Michael, 2006; Pine \& Gilmore, 1999).

There have been a number of studies that have sought to determine the various attributes or elements of an experience. Examples of these attributes include atmosphere (e.g., Bitner, 1992; Heide, Lærdal, \& Grønhaug, 2007), interaction with personnel and other customers (e.g., Heide \& Grønhaug, 2006; Mossberg, 2007), and memorabilia or souvenirs (e.g., Ferdinand \& Williams, 2010; Gordon, 1986). Here we consider that "anything that can be perceived or sensed - or recognized by its absence” (Berry, Carbone, \& Haeckel, 2002, p. 86) is an attribute of an experience so long as it is recalled after the experience process is complete.

Experiences are sought because they offer value to a tourist and a number of authors have sought to determine the value of an experience. Mathwick, Malhotra, and Rigdon (2002) consided that the value of an experience is derived from "interactions involving either direct usage or distanced appreciation of products and services” (2001, p. 41). An experience is considered to offer both extrinsic and intrinsic benefit (e.g., Babin \& Darden, 1995; Mano \& Oliver, 1993). Sandström, Edvardsson, Kristensson, and Magnusson (2008) relate value to the entire experience and define it as "the individual judgment of the sum total of all the functional and emotional experience outcomes” (p. 120).

However, while there have been a number of studies examining experience attributes and experience value, there has been little work on how attributes of a destination link together to express a theme and how these attributes create value for a tourist. The present research aims to examine how the attributes of a destination experience combine together to create a holistic destination experience theme valued by tourists.

\section{WHAT IS A THEME?}

A theme is considered essential for planning and marketing consumer experiences and as a facilitator of the individual involvement in experiential offerings (Pine \& Gilmore, 1998) as it connects separate services and experiential elements together in the visitors mind (Agapito, Oom do Valle, \& da Costa Mendes, 2013). A theme is the 'underlying concept for everything staged in a particular place' (Mossberg, 2007, p. 69). Holbrook and Hirschman (1982) consider a theme is represented by a set of related cues that are intended to evoke a fantasy -an imaginary journey to a different time or place. 
A theme can be incorporated into physical design and used as an attention-creation medium (Slåtten, Mehmetoglu, Svensson, \& Sværi, 2009) providing visual cues to draw more guests. Such cues may be decorations or other more permanent fittings within a venue. Some environments, such as tourist attractions, hotels, and restaurants, are conceptualized as themes derived from stories (Mossberg, 2008) generally built on some believable elements such as a message, conflict, or division of roles and action (Fog, Budtz, \& Yakaboylu, 2003). The use of stories and narratives can "lead to a deeper understanding and ... an

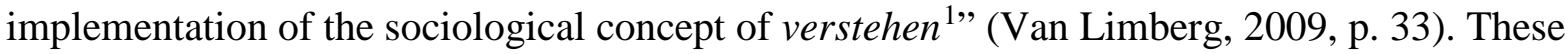
benefits are one reason why storytelling has been widely used, particularly in the tourism industry (Mossberg, 2008), and why fictitious characters, myths, popular books, and films are commonly found in restaurants, theme parks, museums, and destinations. A theme therefore is a strategic element in designing a destination that unites various other elements and directs visitors' attention (Ooi, 2005) and assists visitors to develop meaning from their experiences (Moscardo, Ballantyne, \& Hughes, 2007). Themes help visitors to organize their impressions, leading to increased memorability (Oh, Fiore, \& Jeoung, 2007), and creating value (Agapito, Valle, \& Mendes, 2014; Holbrook \& Hirschman, 1982). A theme may influence sustainable behaviours, length of stay, and commercial revenue (Pearce \& Wu, 2014).

Given the importance of a destination theme, how do we go about identifying or developing thematic experiences for a place? Destinations often grow as places where people live and have a history which is not necessarily thematic. Sometimes a city may have an easily identified theme: a romantic theme (Verona, the setting for Romeo and Juliet), a theme of horror or sadness as in dark tourism (Buchenwald), a cultural or adventure theme, etc. Arnould and Price (1993) identified a number of experiential themes such as pilgrimage, intensification and rediscovery of self, and communion with nature. In other cases, a city or location may reflect a variety of themes (Pearce \& Wu, 2014) and there is a need to shape a destination or attraction's theme for effective communication. An effective theme is dramaturgical, and can be an idea, a subject, or an underlying, permeating 'something' that determines the elements applied to create the experiential context. It should have a widespread emotional appeal (Pearce \& Wu, 2014) and be culturally relevant to visitors to a destination (Xu, Cui, Ballantyne, \& Packer, 2013).

\footnotetext{
${ }^{1}$ Verstehen refers to understanding the meaning of “action from... the actor's point of view” (Schutz, 1954, p. 269).
} 
Tourist destination managers are increasingly seeking to position their destinations as providing experiences (Murphy, Pritchard, \& Smith, 2000; Richards, 2001) rather than as (merely) places to visit. "What tourists primarily seek and consume at destinations are engaging experiences accompanied by the goods and/or service components of the destinations” (Oh, Fiore, \& Jeoung, 2007, p. 119). Experiences are often regarded as the primary factor desired by many tourists (Mo, Howard, \& Havitz, 1993). "Physical plant” (Smith, 1994, p. 588) and service infrastructure support their visit , but a destination is not just these inputs but also an experience in its own right (Murphy et al., 2000; Ross, 1998).

Identifying a destination theme is an important first step in designing attractive visitor experiences. Experiences in a historic city may be designed and constructed to facilitate understanding of its past (Trauer \& Ryan, 2005). Certainly, a tourist's experiences are framed by individual factors such as the reason for the visit, length of stay, and personal relationships. However, the destination elements perceived by a tourist are also important in determining the experiential outcomes of a visit. A tourist's prior knowledge of the destination -in part through the advertising imagery they have been exposed to -also has a pervasive influence on the experiential process, influencing tourist's behaviour (Olivia, 1999), and affecting tourists’ satisfaction and their memories (Gallarza, Saura, \& García, 2002).

Given the central role of a destination experience for understanding why tourists travel, it is surprising that there has been little systematic examination of how the separate and multi-dimensional elements of a destination experience combine to form a coherent theme (Gentile, Spiller, \& Noci, 2007). One problem for systemic study of the destination experience is that an experience attribute is "anything that can be perceived or sensed -or recognized by its absence” (Berry et al., 2002, p. 86). This study provides a framework for the analysis of destination elements based on Pine and Gilmore's (1998) experience framework and its thematic elements, i.e., atmosphere, interaction, memorabilia. Each of these is examined in detail below.

\section{Atmosphere cues}

Atmosphere refers to "...the conscious design of space to create certain effect in buyers" (Kotler, 1973, p. 50), essentially to affect a consumer's five senses. Research concerning the design of a place's atmosphere and its effect on tourists' experiences has been undertaken in the leisure/tourism area for many years (Mossberg, 2007). For example, three types of 
attributes found to influence hospitality experiences are: 1) attributes of the ambient environment, background conditions such as temperature, scent, noise, music, and lighting; 2) attributes of the social environment, the "people” component of the environment; and 3) attributes of the design, including functional and aesthetic elements such as architecture, style, and layout (Heide \& Grønhaug, 2006). Each of these helps to communicate a theme.

The physical component of atmosphere design is usually considered as an attentioncreation medium (Slåtten et al., 2009). Since production and consumption occur simultaneously in tourism, the design of a consumption space not only attracts tourists' attention, but also may be used to influence their actual experiences in a thematic sense. This is because tourists primarily visit places to consume the 'atmosphere' provided by a destination (Echtner \& Ritchie, 1993), rather than the consumption or purchase of goods and services available. In an experiential environment, both the tangible and intangible aspects of the visited space can be simultaneously constructed through the tourist's 'gaze', their perception, and experience.

\section{Interaction cues}

An individual's experience is also influenced by the 'people' component of the environment (Heide \& Grønhaug, 2006; Heide et al., 2007) which can be separated into interactions with employees and with other customers (Mossberg, 2007). Tourist-employee interaction is seen as an important factor that influences perceived experience quality and satisfaction (Bitner, Booms, \& Tetreault, 1990; De Ruyter \& Wetzels, 2000). An employees’ ability to respond appropriately to tourists’ needs or possible service-delivery failures, as well as their unprompted actions affect experiences strongly (Bitner, 1990). Tourists travelling in a destination can be considered to step into 'a special world', but if they have no knowledge of the context, they may have trouble adapting to it and becoming immersed (Carù \& Cova, 2007). Employees, particularly front-line personnel, can be a valuable resource for establishing emotional connections with, and facilitating immersion of, tourists (Zomerdijk \& Voss, 2010). This may occur through their providing support or acting as a helper. For instance, a tour guide can play the role of a source of information for tourists (Josiam, Mattson, \& Sullivan, 2004), as path-finder or mentor (Cohen, 1985), or as mediator between tourists and local scenes (Dahles, 2002), all of which helps to orchestrate the stage of experience. Employee engagement with tourists has been termed emotional labour (Hochschild, 2003; Zomerdijk \& Voss, 2010). It can lead to rapport relating to enjoyable 
interactions, including feelings of care, friendliness, and personal connections based on a genuine interest in others or psychological similarity (Gremler \& Gwinner, 2000) and to authentic understanding, especially important in extended, affective, and intimate service encounters (Price, Arnould, \& Tierney, 1995). Employees who are particularly helpful, and show empathy as well as being very friendly, may induce greater levels of stimulation and pleasure (Slåtten et al., 2009).

Interactions between tourists: tourists' experiences are usually staged in the presence of other tourists (Baker, 1987), who then may affect their perception (Zomerdijk \& Voss, 2010). An excited audience can enhance the experience of its members (Lovelock, 1996). Researchers have studied the positive aspects of being together with other consumers and how these influence a customer’s willingness to be a co-producer (Gummesson, 1993; Silpakit \& Fisk, 1985). This particularly applies to situations in which customers are in close proximity to each other or have to share resources or space simultaneously (e.g., restaurants, airline travel) even when waiting (Kellogg, Youngdahl, \& Bowen, 1997). Meetings between guests in the hospitality context can influence customers' satisfaction (2006). In a dining context, consumers imitate each other in terms of fashions, and may act with artifice and pretence (Finkelstein, 1991). Thus, the dining party members and other diners in a restaurant are also important for the dining experience (Andersson \& Mossberg, 2004; Valentine, 1999).

Interaction and connection with other customers are opportunities to satisfy consumers’ social needs and make experiences more enjoyable (Harris \& Baron, 2004; Nicholls, 2005). These interactions are usually seen as an entrance ticket to a social group or allow a sense of community to develop, and have been studied at motorbike events and sports activities (Hallin \& Mykletun, 2006). Through the sharing of consumption values and behaviour, a consumer can build a sense of community with others, or feel a sense of belonging to a group.

Tourists are co-producers of their own experiences as they are necessary for its performance and production. For some guests, the experience of going to a restaurant may serve the function of "seeing and being seen" in public and being entertained by others (Scapp \& Seitz, 1998). Similarly, some consumers prefer to participate in VIP venues and to interact with other VIPs, because "people who have money want to be seen around other people who have money” (Pullman \& Gross, 2004, p. 556). The companionship and 
emotional support received from other customers leads to high levels of commitment toward future patronage (Rosenbaum, 2006).

\section{Memorabilia - memory cues}

Almost everyone is, to some extent, a collector of memorabilia (Gordon, 1986), because people want to be reminded of special times and activities, and certain goods that are saved can convey their memories (Pine \& Gilmore, 1999) or serve as a reminder of an experience. Memorabilia are usually goods collected or purchased by tourists within a destination to act as "a concrete reminder or tangible way of capturing or freezing a non- or extra-ordinary experience” (Gordon, 1986, p. 137).

For tourists, memorabilia may be the only tangible outcome of their holiday and can reinforce emotional experiences. This partly explains the reason why many tourists often spend more on shopping than on food, lodging, or other activities (Jansen-Verbeke, 1991; Timothy \& Butler, 1995). It should be noted that shopping by itself can also enrich the content of tourist experience, and affect the overall experience of a destination (Onderwater, Richards, \& Stam, 2000). After the trip, memorabilia may serve as "pictorial or symbolic reminders of a destination, markers which commemorate a moment in time, representations of the local environment or cultural artefacts from a particular place or culture” (Ferdinand \& Williams, 2010, p. 207). People wearing memorabilia such as a T-shirt become walking advertisements for the visited destination; thus, their experience is transmitted to others (Pine \& Gilmore, 1999). Memorabilia can also satisfy tourists’ desires for novelty (Lee, Kim, Seock, \& Cho, 2009), authenticity (Littrell, Anderson, \& Brown, 1993), collecting (Squire, 1994), and social status (Pine \& Gilmore, 1999). Therefore, memorabilia is a particularly powerful factor in enhancing experience quality, and the purchase of memorabilia is an integral part of the tourist experience in a destination.

Clearly, an experience is a blend of many perceived attributes coming together (Shaw \& Ivens, 2002) to involve a person emotionally, physically, intellectually, and spiritually (Carbone, 1998; Oswald et al., 2006). No prior study has identified attributes that are embodied in an experience, and how they combine together to create a holistic destination theme that provides value for visitors.

\section{CUSTOMER VALUE}


Zeithaml (1988) provided a fundamental basis for the contemporary concept of customer value. Using a means-end model, she defined customer value as a bi-directional trade-off involving "the consumer's overall assessment of the utility of a product based on perceptions of what is received and what is given” (p. 14). She further suggested that situational or contextual factors affect customer value, subject to the influence of a consumer's reference frame. Zeithaml's (1988) 'give' versus 'get' definition leads to interest in the composite nature of customer value, and was further extended to include what customers get (benefits, quality, worth, utility) from the purchase and use of a product versus what they pay (price, costs, sacrifices) (e.g., Gale, 1994; Heard, 1993), resulting in an attitude toward the product, and even an emotional bond with a product (Butz \& Goodstein, 1996).

The cognitive trade-off concept of value is easy to understand, but it neglects many factors in the consumption process, especially hedonic values of consumer experience (Babin \& Kim, 2001; Chiu, Hsieh, Li, \& Lee, 2005). Therefore, later researchers sought to understand consumers' needs and desires through their purchase of goods, services, or experiences (e.g., Mathwick et al., 2002; Sinha \& DeSarbo, 1998; Sweeney \& Soutar, 2001). However, value as a concept remained associated with either that received or desired. Woodruff (1997) however incorporated both desired and received value defining value as “customer's perceived preference for and evaluation of those product attributes, attribute performances, and consequences arising from use that facilitate (or block) achieving the customer's goals and purposes in use situations” (p. 142). Woodruff 's (1997) definition embodies cognitive tasks (preference for and evaluation of), and levels of assessment criteria (attributes, consequences, and desired end-states). It implies that customers' value judgments are subject and contextspecific, determined within the constraints of a particular use situation rather than product attributes, and emphasizes those derived from customers’ learned perceptions, preferences, and evaluation.

Due to the complexity of the customer value construct, many researchers have sought to understand the categories or dimensions on which customers' assessments are made, using these to create a typology. An early axiological model of value proposed by Hartman (1967, 1973) included extrinsic value, intrinsic value and systemic value, respectively referring to the utilitarian, emotional, and rational aspects of consumption. This three-dimensional structure of value was adapted by Mattsson (1991), who further suggested that the three values are not the same. This finding was supported by Sheth, Newman, and Gross (1991a, 
1991b). They considered that consumer choice is a function of multiple consumption values, which are independent and make differential contributions in different contexts.

The multi-dimensional structure approach to value provided a new direction for subsequent studies (e.g., Sweeney \& Soutar, 2001; Wang, Lo, Chi, \& Yang, 2004) although these studies remained focused on customer value from a customer perspective. Examples include Holbrook's (1994) eight types of customer value and Woodall’s (2003) five primary forms of customer value. Smith and Colgate (2007) on the other hand adopted a strategic marketing orientation and distinguished four major types of customer value that can be created by organizations:

- Functional/instrumental value is concerned with the extent to which a goods or service has desired characteristics, is useful, or performs a desired function.

- Experiential/hedonic value is concerned with the extent to which a goods or service creates appropriate experiences, feelings, and emotions for the customer.

- Symbolic/expressive value is concerned with the extent to which customers attach or associate psychological meaning to a product.

- Cost/sacrifice value is concerned with the transaction costs.

Since experiences originate from a set of complex interactions between the customer and a company or the company’s offerings (Addis \& Holbrook, 2001; Carù \& Cova, 2003), both customer and manager perspectives are required in research on an experience. Smith and Colgate's (2007) typology is applicable not only to consumer contexts, but also to business contexts. It is a useful tool for managers to specify and illustrate value creation strategies, identify opportunities for new value creation propositions, and suggest enhancements to the value propositions of existing goods or services. Considering its strategic marketing orientation, Smith and Colgate's four types of customer value are adopted for this research.

\section{METHODS}

Due to the scant theoretical insight into what particular attributes are embodied in experiences, and how they combine together to create a holistic destination experience for tourists, a case study and qualitative methodology were considered appropriate as it can provide in-depth, rich data. Zhouzhuang, China was selected as the case for its thematic, atmospheric and social characteristics. It is a historical water town of China, with local 
dwellings having a unique architectural structure clustered on the bank of rivers or lakes. It is located to the south of the Yangtze River, 38km from central Suzhou and 60km from Shanghai Airport. The town developed during the Ming (1368-1644) and Qing (1644-1911) dynasties, and has been considered one of the world's most beautiful towns (Gerrie, 2012) providing a rich historical and cultural experience for tourists. The river-based settlement appeals to the primarily Chinese tourists for two main reasons: first, the historic and cultural heritage of ancient towns is different from modern cities and attractive for its geographical configuration, buildings, and traditional features; second, the atmosphere of water towns supports the theme of harmony between nature and residents. The destination theme of Zhouzhuang is evoked by the famous Chinese verse -“small bridge, flowing water, and

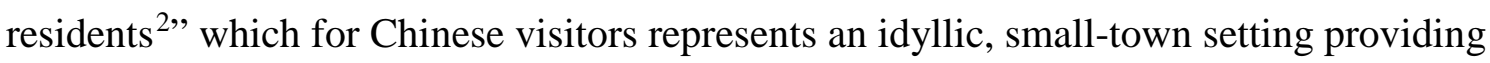
residents of large cities to fulfil their fantasy of escaping from their noise, pollution, and pressure (Ruan \& Shao, 1996). The beautiful riverside scenery has attracted many Chinese writers, poets, and artists. Over the past twenty years, this ancient town has hosted a large number of domestic tourists and a growing number from overseas. Well known symbols of Zhouzhuang related to its theme include the image of white wall, black tiles, small bridges, and rivers, and the simple and traditional ways of life.

Data collection started in Zhouzhuang in June 2011 and began with six qualitative indepth interviews with tourists to become familiar and comfortable with the protocol and respondent interaction. The main data collection was conducted on weekdays from July to November 2011. The informants were all first time Chinese overnight tourists to minimize the impact of previous knowledge and experience of Zhouzhuang. All interviews were conducted in riverside restaurants or teahouses either after 8pm or before 9am, when tourists were more likely to agree to participate and the interviews were less likely to be interrupted. The trained Chinese speaking investigators approached tourists, outlined the purpose of the research, and invited them to participate in an interview. Once the invitation was accepted, several screening questions were asked: “Is this the first time for you to visit Zhouzhuang?” “Did you or are you going to stay here for the night?” "When are you going to finish your trip in Zhouzhuang?” Only the tourists whose answers for the first two questions were both "yes" and who had finished or almost finished their trips were regarded as targets for further

\footnotetext{
2 This well-known phrase is from a Yuanqu song popular in the Yuan Dynasty. The song is named "Sand and Sky: Autumn Thoughts”, written by Zhiyuan Ma (1250-1324). This verse originally expresses the author's longing for his family, and then gradually became synonymous with the water towns in the south of the Yangtze River and seen as a true reflection of these water towns.
} 
conversation. If the tourists were in a group, the investigators would ask them to recommend one tourist to answer all interview questions. The saturation point (Glaser \& Strauss, 1980) was reached after 63 participants (identified by a code number) had been interviewed. After transcription, data from the interviews was analysed using content analysis procedures supported by qualitative data analysis software NVivo 9.2. Latent coding was used and combined with manifest coding for data reduction. Tree-structured catalogues were created for the experience attributes perceived by tourists (Richards, 2009) and named using the topics of coding text (e.g., 'Folk House') or with the words that interviewees themselves used (e.g., 'Lots of Tourists').

In analysing the transcripts, it was noted that attributes of different types were often mentioned by participants in the same sentence. For example, the sentence "We...chose a small waterside teahouse to... have some tea....[TP62]" was coded as embodying the theme “Small Bridge, Flowing Water, \& Residents", the atmospheric attributes of "Waterside Dwellings" and “Tea”, and a service attribute -“Catering”. Similarly, the sentence "I took a photo with my girlfriend around the Twin Bridge, what a memorable moment for us [TP11]" was coded as involving atmosphere (“Bridge \& River”), interaction (“Friends \& Family”) and memorabilia ("Photographs \& Postcards”) as shown in Table 1.

\section{TABLE 1 ABOUT HERE}

An attribute was considered to be linked to a theme if they co-occurred in a same sentence (see Table 1). The frequency of attribute and theme co-occurrence was determined using an NVivo Matrix Coding Query. NVivo 9.2 was used to create tables of codes cooccurrences, which “...enables the analyst to compute associations but also serves as an entry to contingency analysis” (Krippendorff, 2004, pp. 268-269). Furthermore, “the frequency of co-occurrence of two concepts ... indicate[s] the strength of associations between those concepts in the minds of the members” (p. 59), therefore this research conducted a quantitative analyses of the coded data, i.e., a count of co-occurrences, especially their frequency of appearance (Huberman \& Miles, 1994). This helps with data reduction and “may make data more accessible” (Henderson, 2006, p. 167). This method has been used in 
previous descriptive research (Bonet \& Paché, 2005; Henderson, 2006; Richards, 2009; Yaghmour \& Scott, 2009).

\section{FINDINGS}

Some 54 unique attributes perceived by tourists during their experience in Zhouzhuang were identified and are shown in Table 2. These attributes were classified into four types: atmosphere, interactions, and memorabilia as discussed in the literature review and another type of attribute called service. Analysis of interview transcripts identified the theme, 'Small Bridge, Flowing Water, and Residents' associated with the famous Chinese verse as central to the experience in Zhouzhuang. This theme was discussed by all 63 respondents and a total of 341 occurrences were noted (an average of over five times per tourist). Because of space limitations, only the linkage between the theme and attributes for the top 10 most frequently occurring attributes (called the “Top10” for short, marked as “*” in Table 2) are discussed here. The linkage between tourists' perceived attributes and their perception of value in Zhouzhuang are also shown in Table 2.

\section{TABLE 2 ABOUT HERE}

\section{Themes and attributes}

The theme 'Small Bridge, Flowing Water, and Residents' was strongly associated with the town's atmosphere -this was a focus for respondents during the interviews - and half the Top10 are atmosphere attributes. 'Boats \& Boat-ladies' and 'Siting along the Waterside' were commonly mentioned as were words related to water scenery, including "water town", "bridge”, "water” or "river", "waterside” or "riverside”, "small bridge and flowing water", and "small bridge, flowing water, and residents". Tourists appear to have been 'primed' by their previous knowledge about Zhouzhuang and this prior knowledge formed a main focus of their experiences in the town:

There are so many water factors in this small water town: bridges, residents, houses, and boats... All these things combine together and match so well. The only word I can say is exquisite. [TP22] 
Atmosphere was most frequently mentioned and associated with the senses (i.e., 'Sights', 'Sound', 'Taste', 'Touch or Feeling', 'Scent', and 'Own Activities') and with 'Local Delicacies \& Snacks’.

Interactions with 'Personnel', 'Local Residents', and ‘Other Tourists' were also found to help create the theme. There was one interaction attribute in the Top10, in other words, interactions with 'Local Residents' were mentioned more frequently than that with others. More than 800 indigenous families live in Zhouzhuang and many of them participate in tourism through traditional handicraft displays or providing houses for accommodation, restaurant, and snack bars. These residents have not changed their conventional lifestyle, but their ordinary lives overlap with tourism, especially through staged activities and supporting services. Local residents' 'naturally' perform for tourists, so they were commonly regarded as part of the cultural background and related to the water culture theme, as shown below:

We heard some folk songs sung by a local granny - it was such a lovely night in the town. [TP01]

Interaction with other tourists was mostly a negative aspect of the visit as there were considered too many. However, respondents' concerns about these interactions differed according to the time of their visit. Many tourists had anticipated that there might be lots of other tourists because “Zhouzhuang is a famous tourist destination in China” [TP08], but the number of tourists was sometimes bigger than their expectations and led to a worse experience. This was especially noted during daytime, evidenced by respondents frequently mentioning there were 'Lots of Tourists'. As a result, they complained:

There is nothing to see, except for tourists, even in the photographs I took. [TP41]

While 'Lots of Tourists' was frequently mentioned as part of daytime experiences, the 'authentic' Zhouzhuang could be experienced at night and in the early morning when few others were around. Therefore tourists experienced the theme 'Small Bridge, Flowing Water, and Resident' differently at night and during the day. No memorabilia attribute was listed in the Top 10, but when it was, the most frequently mentioned memorabilia were 'Photographs \& Postcards'.

Four service attributes were listed in the Top10. Many respondents mentioned attributes related to service activities including: taking a boat (i.e., 'Boating'), having dinner 
(i.e., 'Catering'), seeing the show (i.e., 'Entertainment'), living in a waterside house (i.e., 'Guest House \& Lodge'), and shopping (i.e., 'Goods \& Shops'). All tourists were overnight visitors; therefore catering and accommodation were basic services that all they received. However, these service providers were chosen because they were involved in experiencing the town's theme. For example, many tourists had meals, tea, or even relaxed beside the river, so they could see and hear the "Boats \& Boat-ladies" passing by. When describing the 'Guest House \& Lodge' in which they lived, tourists often said they chose their accommodation based on local 'Life-Style', as represented by “carved bed”, “folk house”, or "waterside dwelling". Therefore, these services were chosen because they were regarded "to be ... a part of local life". Whether staying in a small inn or a formal hotel, many tourists described their accommodation with names that usually contained the Chinese word “水” (literally “water”). As one respondent said: "regarding the name, I can imagine a river running around the inn, which is just what I want". Therefore, services helped to communicate the theme of the town.

\section{Customer value from attributes}

Tourists often started their descriptions with concerns about the extent to which the attributes were useful or performed a desired function for them, that is, provided functional value. Table 2 shows that nine of the top 10 most relevant attributes providing functional value are service attributes, with only one in the interaction group. This is not only because tourists found those attributes of use, but also because they were dissatisfied, for example:

At night, tourists, like me, like to stroll in the town. Many beautiful red lanterns are lit along the rivers, but there are only a few lamps in some narrow streets. I am not brave enough to go to those dark streets as a female lone traveller. [TP44]

Almost all attributes except for some service attributes were linked to experiential value. All tourists were first time visitors to Zhouzhuang, and for these people many attributes of the town, especially the atmosphere attributes, had epistemic value relating to knowledge, novelty, and fantasy.

It is rare to see those traditional and live fabricated handicrafts in modern cities. [TP30] 
Atmosphere and memorabilia mostly related to sensory value. When respondents deeply engaged in an activity, they experienced emotional responses such as fun, nostalgia, and euphoria.

When sitting on a bridge, a fisherman was catching fish by using tame cormorants, a lady wearing the traditional dress was swinging a boat, and several old ladies were singing folk ditties... all of these made me nostalgic for the past. [TP27]

During their experience in Zhouzhuang, especially during various activities they undertook, tourists interacted with local residents and other tourists which provided experiential value.

Before we left the inn this morning, the owner was so nice that he gave us a calling card and said that he could direct us if we lost our way in the town. [TP33]

Zhouzhuang delivered symbolic value when it communicated the attributes and theme respondents expected before their visit. Tourists expressed satisfaction with the "achievement of their travel wishes", others were proud to "see the real town" after comparing what they had seen in paintings or pictures of the town, or with their “imagination”. They were often able to vividly describe their experiences, especially those that were new and surprising, such as "watching a live wedding ceremony", "tasting bean jelly”, or "listening to Pingtan". Thus the experiences in Zhouzhuang provided them with a sense of symbolic value. Furthermore, tourists often associated some attributes with special events or other people, especially with their travel companions. For them, attributes became private symbols, for example:

We strolled in the town, and then took a boat. Taking a boat in a water town made us feel romantic and affectionate...and was very memorable. [TP57]

Tourists often chose a service for symbolic reasons. Thus to "have dinner along waterside", "live in a waterside inn", and "sleep in a carved bed" all had symbolic meaning related to local culture or tradition, and receiving this service led to emotional responses, such as relaxation and nostalgia. Respondents mentioned that such services meant they could "be as much a part of local life as [they] can" or could "escape from busy daily life". Another said: 
I had some tea when I listened to Kun Opera, I feel like an old local man...haha... I am kidding! The rhythm was slow and I felt quite relaxed. [TP53]

Almost all tourists commented on the transaction cost of their experience in Zhouzhuang, mainly focusing on the money it cost and the time they spent. Table 2 demonstrates that participants' assessments of cost value were mainly derived from the service and memorabilia attributes, which is because major activities that tourists paid for and participated in were directly related to the services provided. For example, some tourists discussed positive interaction with other tourists, that is, they shared services such as tour guides, entertainment, and boating, while some attributed non-participation in some activities to the price.

Table 2 shows that attributes were associated with multiple types of customer value, but that there were some common relationships. Atmospheric attributes were related to experiential and symbolic value; interaction attributes were related to functional value and experiential value; memorabilia and service attributes were related with many types of customer value.

\section{DISCUSSION AND CONCLUSION}

An experience is a blend of many elements that come together (Shaw \& Ivens, 2002) to involve consumers emotionally, physically, intellectually, and spiritually (Carbone, 1998; Oswald et al., 2006; Pine \& Gilmore, 1999). However, no previous study has identified how these attributes link together and how they create value for tourists at the destination level. This paper has found that attributes can be clustered together into four types and can be related to particular types of value.

The finding that all this destinations attributes were able to be clustered into four types is important. Prior academics have noted that various attributes can influence customer experience (e.g., Edvardsson, Enquist, \& Johnston, 2005; Pullman \& Gross, 2004; Zomerdijk \& Voss, 2010), but no prior study has identified the clusters of attributes found in a destination context. This study has found four such clusters of attributes: atmosphere, interactions, memorabilia, and service. Previous studies have usually examined only one such type (e.g., Slåtten et al., 2009) and no study has examined all these types in a destination. These attribute types provide an analytical framework that useful for analysis of 
other experiences. This framework will enable better analysis of tourism destination experiences.

The link between the theme and attributes is also an important finding of this research. The attributes perceived by tourists to Zhouzhuang were related to a theme that was strongly linked with the town's atmospheric attributes. It appears that such atmospheric attributes are especially effective in evoking a theme. Atmospheric attributes such as architectures and songs appear to more easily take a customer on an imaginary journey to a different time or place (Holbrook \& Hirschman, 1982). In Zhouzhuang, tourists’ consumption of 'atmosphere' was guided by their previous knowledge of the town. The 'Small Bridge, Flowing Water, and Residents' theme attracted tourists to visit Zhouzhuang, and also directed their attention to the attributes linked to that theme during their visit. This theme is an important part of the destination image and influenced potential tourist's decision-making behaviour, as well as their subjective perception during the visit (Olivia, 1999). It appears that atmosphere attributes are important in developing a destination theme, and that in developing a destination image, managers should identify and develop important atmosphere attributes.

In Zhouzhuang, the 'Small Bridge, Flowing Water, and Residents' theme was strongly linked to service activities such as boating or a local life-style lodge that enabled tourists to experience local residents' lives. These activities also involved tourists through use of their five senses. The memorabilia purchased from local shops were often seen not only as symbols of water culture theme, but also as tangible reminders (Gordon, 1986) to reinforce 'memories' cherished and consumed 'after' the trip, and thus made the ephemeral experience last longer (Haldrup \& Larsen, 2003).

A tourist's experience of Zhouzhuang was also influenced by their interactions with other people (Zeithaml, Bitner, \& Gremler, 2008). In Zhouzhuang, many activities involved interactions between tourists and personnel, local residents, travel companions or other tourists. The nature of these interactions differed between day and night time. During the day, crowding usually led to negative interactions among tourists and influenced their perceptions of atmosphere attributes. At night, fewer tourists encouraged more positive interactions and tourists engaged in more self-designed activities with their travel companions. The quiet night atmosphere, more self-directed activities, and more positive interactions with other 
people led to tourists experiencing the theme differently at night. Therefore, interactions with other tourists influenced the theme and atmosphere that tourists perceived.

These results indicate that the theme perceived by tourists was linked to the atmosphere, interaction, memorabilia, and service they experienced as shown in Table 2. In previous studies, a theme is considered from a managerial perspective to be incorporated into physical design focusing on the environment (Slåtten et al., 2009). This study found a theme, from a tourist perspective, requires coherence not just in the designed physical environment; it must also involve other attributes such as interaction, service, and memorabilia. Because interactions and service are involved in creation of an experience, they are dynamic and associated with the visitation process, so the progression and duration of the visit become important components of an experience (Zomerdijk \& Voss, 2010). As a result, the “omnipresence” of a theme (Kozinets et al., 2002, p. 23) is reaffirmed. Therefore, theme encompassed all types of attributes, such as atmosphere, interaction, memorabilia, and service. Due to the scant theoretical insight into how these elements blend together at the destination level, this research is the first to empirically identify the perceived attributes and the linkages between them embodied in a destination experience.

The final finding is that all perceived attributes can be assessed with multiple types of customer value, but different types of attributes may be mainly assessed with different types of value. Previous studies of customer value focused on its consequences, that is, how customer value can influence consumer behaviours, while there are few studies about its antecedents, that is, what factors can influence perceived customer value. Those few studies either test the effects of some special factors on perceived customer value (e.g., Baker, Parasuraman, Grewal, \& Voss, 2002), or test different factors (e.g., scents, music, and colour) on one type of customer value (e.g., Naylor, Kleiser, Baker, \& Yorkston, 2008). No previous study in the general literature or in the tourism area, however, has systematically identified the linkage between different types of attributes and perceived customer value of an experience. This research explicates how experience attributes affect customer value. The result can suggest enhancements to the value propositions of existing experiences by examining which attributes may be manipulated to influence tourists' perceptions, and thus help managers to better serve tourists by moving resources to these areas, or identify opportunities for new value creation propositions. 
This research examines attributes of a destination experience and their communications to a theme and customer value, which provides a useful method for destination managers to support the purposive design of the tourist experience. However, this research must acknowledge limitations in the sampling of tourists and its basis on only one qualitative case. The results of the study were only obtained from Chinese overnight tourists limiting the generalization of the results to Chinese people who visited Zhouzhuang during the working day. In addition Zhouzhuang is a cultural and heritage destination, thus the linkage between the theme and the service attributes may not apply in many other contexts or be as strong. Therefore, similar studies are recommended in different research contexts, such as other types of tourist destinations, hotels, events, and festivals to test this enhanced framework. 
Table 1 Examples of perceived attributes assigned to different types and the theme

\begin{tabular}{|c|c|c|c|c|c|}
\hline \multirow{2}{*}{ No. } & \multirow{2}{*}{ Theme } & \multicolumn{4}{|c|}{ Types of perceive attributes } \\
\hline & & Atmosphere & Interaction & Memorabilia & Service \\
\hline \multirow[t]{2}{*}{1} & \multicolumn{5}{|c|}{ We...chose a small waterside teahouse to... have some tea.... [TP62] } \\
\hline & $\begin{array}{l}\text {-Small Bridge, Flowing } \\
\text { Water, \& Residents }\end{array}$ & $\begin{array}{l}\text { •Sight } \\
\text { LFolk House } \\
\quad\llcorner\text { Waterside Dwellings } \\
\text { •Taste } \\
\quad \text { Tea }\end{array}$ & & & $\begin{array}{l}\text { - Catering } \\
\llcorner\text { Waterside }\end{array}$ \\
\hline \multirow[t]{2}{*}{2} & \multicolumn{5}{|c|}{ I took a photo with my girlfriend around the Twin Bridge, what a memorable moment for us [TP11] } \\
\hline & & $\begin{array}{l}\text { • Sight } \\
\text { ட Ancient Water Town } \\
\quad \text { ட Bridge \& River }\end{array}$ & $\begin{array}{l}\text { •Other Tourists } \\
\text { L Friends \& Family }\end{array}$ & •Photographs \& P & \\
\hline
\end{tabular}


Table 2 Node matrices of the linkage between attributes and the theme and the linkage between attributes and four types of customer value

\begin{tabular}{|c|c|c|c|c|c|c|}
\hline \multirow[b]{2}{*}{ Attributes } & & \multirow{2}{*}{$\begin{array}{c}\text { Theme } \\
\begin{array}{c}\text { Small Bridge, Flowing } \\
\text { Water, \& Residents }\end{array}\end{array}$} & \multicolumn{4}{|c|}{ Customer Value } \\
\hline & & & Functional Value & Experiential Value & \multirow[t]{2}{*}{ Symbolic Value } & \multirow[t]{2}{*}{ Cost Value } \\
\hline Atmosphere & & & & & & \\
\hline \multirow[t]{16}{*}{ Sight } & • Ancient Water Town & 9 & - & 49 & 20 & 13 \\
\hline & Boats \& Boat-ladies & $81 *$ & 6 & $75 \#$ & 17 & - \\
\hline & Bridge \& River & $91 *$ & 15 & $103 \#$ & $22 \#$ & - \\
\hline & Rain & 4 & - & 9 & - & - \\
\hline & Folk House & 17 & - & 32 & 2 & - \\
\hline & Carved Bed & 13 & - & 14 & 5 & - \\
\hline & Old Buildings & 18 & 2 & 17 & 5 & - \\
\hline & Waterside Dwellings & $61 *$ & - & 69 & $23 \#$ & - \\
\hline & Narrow Streets \& Alleys & 21 & 5 & 36 & 4 & - \\
\hline & Traditional Dresses & 6 & - & 7 & 1 & - \\
\hline & Traditional Lifestyle & $49 *$ & 2 & 67 & 19 & - \\
\hline & Slow Life & 22 & 2 & 36 & 10 & - \\
\hline & Night View & 21 & 7 & $115 \#$ & 19 & - \\
\hline & Lantern \& Lamplight & 9 & - & 52 & 7 & - \\
\hline & View of Early Morning & 5 & 2 & 20 & 3 & 1 \\
\hline & • 'Zhouzhuang in All Seasons' & 11 & - & 14 & 3 & - \\
\hline \multirow[t]{4}{*}{ Sound } & • Folk Songs & 34 & 2 & 39 & 11 & - \\
\hline & • Kun Opera \& Pingtan & 7 & - & 16 & 4 & - \\
\hline & • Legends of Shen & - & - & 21 & 1 & - \\
\hline & • Wu Dialect & 14 & - & 17 & 2 & - \\
\hline \multirow[t]{2}{*}{ Taste } & • Local Delicacies \& Snacks & 7 & - & $101 \#$ & 3 & - \\
\hline & • Tea & 14 & - & 24 & 7 & - \\
\hline Touch/Feeling & • Touch or Feeling & 7 & 8 & 16 & 4 & - \\
\hline Scent & • Scent & - & 1 & 4 & 1 & - \\
\hline \multirow{2}{*}{ Own Activities } & - Rambling in the Town & 8 & 5 & 23 & 10 & - \\
\hline & - Sitting along Waterside & $35 *$ & 15 & 54 & 15 & - \\
\hline \multirow[t]{10}{*}{ Interactions } & & & & & & \\
\hline & • Personnel & 31 & 19 & 70 & 3 & - \\
\hline & Boat-ladies \& Boatmen & 23 & 8 & 27 & - & - \\
\hline & Performers & 10 & 9 & 23 & 3 & - \\
\hline & Tourist Guide & - & 2 & 20 & - & - \\
\hline & • Local Residents & $59 *$ & 18 & 78 & - & - \\
\hline & • Other Tourists & 21 & $107 \#$ & 25 & - & 8 \\
\hline & Friends \& Family & 5 & 1 & 59 & 10 & 1 \\
\hline & Lots of Tourists & 7 & 11 & 79 & - & 1 \\
\hline & Few Tourists & 9 & 2 & 10 & - & - \\
\hline \multirow[t]{7}{*}{ Memorabilia } & & & & & & \\
\hline & • Local Goods & 1 & 18 & 18 & 17 & 5 \\
\hline & • Local Snacks & 3 & 30 & 30 & $30 \#$ & 1 \\
\hline & $\begin{array}{l}\text { • Chinese Painting \& } \\
\text { Calligraphy }\end{array}$ & 11 & 12 & 14 & 13 & 2 \\
\hline & - Photographs \& Postcards & 14 & 24 & 13 & $21 \#$ & - \\
\hline & • Live Fabrication & 7 & 11 & 11 & 10 & - \\
\hline & - Others & 1 & 23 & 21 & 17 & 7 \\
\hline \multirow[t]{14}{*}{ Service } & & & & & & \\
\hline & • Catering & 26 & $219 \#$ & - & $67 \#$ & 34 \\
\hline & Waterside & 12 & 26 & - & $26 \#$ & - \\
\hline & - Guest House \& Lodge & $39 *$ & $89 \quad \#$ & - & $74 \#$ & 27 \\
\hline & Life-Style & $34 *$ & $31 \#$ & - & $34 \#$ & 1 \\
\hline & - Entertainment & $41 *$ & $94 \#$ & - & $58 \#$ & 11 \\
\hline & • Boating & $54 *$ & $69 \#$ & - & $63 \#$ & 8 \\
\hline & - Goods \& Shops & 18 & $125 \#$ & - & 1 & 11 \\
\hline & • Lighting & 8 & $57 \#$ & - & 20 & - \\
\hline & • Tour Guide & - & $110 \#$ & - & 2 & 4 \\
\hline & • Signs & 30 & $105 \#$ & - & - & 1 \\
\hline & • Environmental Quality & 5 & 28 & - & - & - \\
\hline & Water Quality & 3 & 11 & - & - & - \\
\hline & - Online Reservations & - & 14 & - & - & 2 \\
\hline
\end{tabular}


Note. The numbers in each cell indicate the co-occurrence frequency from a matrix coding query by NVivo. - denotes the number of cooccurrence is $0 .{ }^{*}$ denotes the top 10 most relevant perceived attributes for the theme. \# denotes co-occurrence numbers are among the top 10 most relevant perceived attributes for each type of customer value. 


\section{REFERENCE}

Addis, M., \& Holbrook, M. B. (2001). On the conceptual link between mass customisation and experiential consumption: An explosion of subjectivity. Journal of Consumer Behaviour, 1(1), 50-66.

Agapito, D., Oom do Valle, P., \& da Costa Mendes, J. (2013). The Cognitive-AffectiveConative Model of Destination Image: A Confirmatory Analysis. Journal of Travel \& Tourism Marketing, 30(5), 471-481. doi: 10.1080/10548408.2013.803393

Agapito, D., Valle, P., \& Mendes, J. (2014). The sensory dimension of tourist experiences: Capturing meaningful sensory-informed themes in Southwest Portugal. Tourism Management, 42(0), 224-237. doi: http://dx.doi.org/10.1016/j.tourman.2013.11.011

Andersson, T. D., \& Mossberg, L. (2004). The dining experience: Do restaurants satisfy customer needs? Food Service Technology, 4(4), 171-177. doi: 10.1111/j.14715740.2004.00105.X

Arnould, E., \& Price, L. L. (1993). River Magic: Extraordinary Experience and the extended service encounter. Journal of Consumer Research, 20(June), 24-45.

Babin, B. J., \& Darden, W. R. (1995). Consumer self-regulation in a retail environment. Journal of Retailing, 71(1), 47-70.

Babin, B. J., \& Kim, K. (2001). International students' travel behavior: A model of the travelrelated consumer/dissatisfaction process. Journal of Travel \& Tourism Marketing, 10(1), 93-106.

Baker, J. (1987). The role of the environment in marketing services: The consumer perspective. In J. A. Czepiel, C. A. Congram \& J. Shanahan (Eds.), The Services Challenge: Integrating for Competitive Advantage (pp. 79-84). Chicago, IL: American Marketing Association.

Baker, J., Parasuraman, A., Grewal, D., \& Voss, G. B. (2002). The influence of multiple store environment cues on perceived merchandise value and patronage intentions. Journal of Marketing, 66(2), 120-141.

Berry, L. L., Carbone, L. P., \& Haeckel, S. H. (2002). Managing the total customer experience. MIT Sloan Management Review, 43(3), 85-89.

Bitner, M. J. (1990). Evaluating service encounters: The effects of physical surroundings and employee responses. Journal of Marketing, 54(2), 69-82.

Bitner, M. J. (1992). Servicescapes: The impact of physical surroundings on customers and employees. Journal of Marketing, 56(2), 57-71.

Bitner, M. J., Booms, B. H., \& Tetreault, M. S. (1990). The service encounter: Diagnosing favorable and unfavorable incidents. Journal of Marketing, 54(1), 71-84.

Bonet, D., \& Paché, G. (2005). A new approach for understanding hindrances to collaborative practices in the logistics channel. International Journal of Retail \& Distribution Management, 33(8), 583-596. doi: 10.1108/09590550510608386

Boorstin, C. (1964). The Image: A Guide to Pseudo-Events in American Society. New York, NY: Harper \& Row.

Butz, H. E. J., \& Goodstein, L. D. (1996). Measuring customer value: Gaining the strategic advantage. Organizational Dynamics, 24(3), 63-77.

Carù, A., \& Cova, B. (2003). Revisiting consumption experience: A more humble but complete view of the concept. Marketing Theory, 3(2), 267-286. doi: $10.1177 / 14705931030032004$

Carù, A., \& Cova, B. (2007). Consumer immersion in an experiential context. In A. Carù \& B. Cova (Eds.), Consuming Experience (pp. 34-47). Abingdon, UK: Routledge.

Carbone, L. P. (1998). Total customer experience drives value. Management Review, 87(7), 62. 
Chiu, H. C., Hsieh, Y. C., Li, Y. C., \& Lee, M. (2005). Relationship marketing and consumer switching behavior. Journal of Business Research, 58(12), 1681-1689. doi:

10.1016/j.jbusres.2004.11.005

Clawson, M. (1963). Land and Water for Recreation: Opportunities, Problems, and Policies. Chicago, IL: Rand McNally.

Cohen, E. (1979). A phenomenology of tourist experiences. Sociology, 13(2), 179-201. doi: $10.1177 / 003803857901300203$

Cohen, E. (1985). The tourist guide: The origins, structure and dynamics of a role. Annals of Tourism Research, 12(1), 5-29. doi: 10.1016/0160-7383(85)90037-4

Dahles, H. (2002). The politics of tour guiding: Image management in Indonesia. Annals of Tourism Research, 29(3), 783-800. doi: 10.1016/s0160-7383(01)00083-4

Dann, G. M. S. (1977). Anomie, ego-enhancement and tourism. Annals of Tourism Research, 4(4), 184-194. doi: 10.1016/0160-7383(77)90037-8

De Ruyter, K., \& Wetzels, M. (2000). The impact of perceived listening behavior in voice-tovoice service encounters. Journal of Service Research, 2(3), 276-284. doi: 10.1177/109467050023005

Echtner, C. M., \& Ritchie, J. R. B. (1993). The measurement of destination image: An empirical assessment. Journal of Travel Research, 31(4), 3-13. doi: 10.1177/004728759303100402

Edvardsson, B., Enquist, B., \& Johnston, R. (2005). Cocreating customer value through hyperreality in the prepurchase service experience. Journal of Service Research, 8(2), 149-161.

Ferdinand, N., \& Williams, N. L. (2010). Tourism memorabilia and the tourism experience. In M. Morgan, P. Lugosi \& J. R. B. Ritchie (Eds.), The Tourism and Leisure Experience: Consumer and Managerial Perspectives (pp. 202-217). Bristol, UK: Channel View Publications.

Finkelstein, J. (1991). Dining Out. Cambridge, NY: New York University Press.

Fog, K., Budtz, C., \& Yakaboylu, B. (2003). Storytelling: Branding in practice. Frederiksberg, Danmark: Samfundslitteratur.

Gale, B. T. (1994). Managing Customer Value:Creating Quality and Service That Customers Can See. New York, NY: Free Press

Gallarza, M. G., Saura, I. G., \& García, H. C. (2002). Destination image: Towards a conceptual framework. Annals of Tourism Research, 29(1), 56-78. doi: 10.1016/s0160-7383(01)00031-7

Gentile, C., Spiller, N., \& Noci, G. (2007). How to sustain the customer experience: An overview of experience components that co-create value with the customer. European Management Journal, 25(5), 395-410. doi: 10.1016/j.emj.2007.08.005

Gerrie, A. (2012, May 18). World's most beautiful towns [Online forum comment]. Retrieved from http://www.cnngo.com/explorations/escape/worlds-most-beautiful-towns580013?page $=0,1$

Glaser, B. G., \& Strauss, A. L. (1980). The Discovery of Grounded Theory: Strategies for Qualitative Research. Piscataway, NJ: Transaction Publishers.

Gordon, B. (1986). The souvenir: Messenger of the extraordinary. Journal of Popular Culture, 20(3), 135-146. doi: 10.1111/j.0022-3840.1986.2003_135.x

Gremler, D. D., \& Gwinner, K. P. (2000). Customer-employee rapport in service relationships. Journal of Service Research, 3(1), 82-104. doi:

10.1177/109467050031006

Gummesson, E. (1993). Quality Management in Service Organizations: An Interpretation of the Service Quality Phenomenon and a Synthesis of International Research. New York, NY: International Service Quality Assiciation. 
Gustafsson, I. B., Öström, Å., Johansson, J., \& Mossberg, L. (2006). The five aspects meal model: A tool for developing meal services in restaurants. Journal of Foodservice, 17(2), 84-93. doi: 10.1111/j.1745-4506.2006.00023.x

Haldrup, M., \& Larsen, J. (2003). The family gaze. Tourist Studies, 3(1), 23-46. doi: $10.1177 / 1468797603040529$

Hallin, C., \& Mykletun, R. (2006). Space and place for BASE: On the evolution of a BASEjumping attraction image. Scandinavian Journal of Hospitality \& Tourism, 6(2), 95117. doi: 10.1080/15022250600667466

Harris, K., \& Baron, S. (2004). Consumer-to-consumer conversations in service settings. Journal of Service Research, 6(3), 287-303. doi: 10.1177/1094670503260132

Hartman, R. S. (1967). The Structure of Value: Foundations of Scientific Axiology. Carbondale, IL: Southern Illinois University Press.

Hartman, R. S. (1973). The Hartman Value Profile (HVP): Manual of Interpretation. Muskegon, MI: Research Concepts.

Heard, E. (1993). Walking the talk of customer value. National Productivity Review, 13(1), 21-27. doi: 10.1002/npr.4040130105

Heide, M., \& Grønhaug, K. (2006). Atmosphere: Conceptual issues and implications for hospitality management. Scandinavian Journal of Hospitality and Tourism, 6(4), 271286.

Heide, M., Lærdal, K., \& Grønhaug, K. (2007). The design and management of ambience-Implications for hotel architecture and service. Tourism Management, 28(5), 13151325. doi: 10.1016/j.tourman.2007.01.011

Henderson, K. A. (2006). Dimensions of Choice: A Qualitative Approach to Recreation, Parks, and Leisure Research (2nd ed.). State College, PA: Venture Publishing.

Hochschild, A. R. (2003). The Managed Heart: Commercialization of Human Feeling (2nd ed.). Berkeley, CA: University of California Press.

Holbrook, M. B. (1994). The nature of customer value: An axiology of services in the consumption experience. In R. T. Rust \& R. L. Oliver (Eds.), Service Quality: New Directions in Theory and Practice (pp. 21-71). Thousand Oaks, CA: SAGE.

Holbrook, M. B., \& Hirschman, E. C. (1982). The experiential aspects of consumption: Consumer fantasies, feelings, and fun. Journal of Consumer Research, 9(2), 132-140.

Hosany, S., \& Witham, M. (2010). Dimensions of cruisers' experiences, satisfaction, and intention to recommend. Journal of Travel Research, 49(3), 351-364. doi: $10.1177 / 0047287509346859$

Huberman, A. M., \& Miles, M. B. (1994). Data management and analysis methods. In N. K. Denzin \& Y. S. Lincoln (Eds.), Handbook of Qualitative Research (pp. 428-444). Thousand Oaks, CA: SAGE.

Jansen-Verbeke, M. (1991). Leisure shopping: A magic concept for the tourism industry? Tourism Management, 12(1), 9-14. doi: 10.1016/0261-5177(91)90024-n

Josiam, B. M. B. M., Mattson, M., \& Sullivan, P. (2004). The historaunt: Heritage tourism at Mickey's dining car. Tourism Management, 25(4), 453-461. doi: 10.1016/s02615177(03)00126-2

Kellogg, D. L., Youngdahl, W. E., \& Bowen, D. E. (1997). On the relationship between customer participation and satisfaction: Two frameworks. International Journal of Service Industry Management, 8(3), 206-219.

Kotler, P. (1973). Atmospherics as a marketing tool. Journal of Retailing, 49(4), 48-64.

Kozinets, R. V., Sherry, J. F., DeBerry-Spence, B., Duhachek, A., Nuttavuthisit, K., \& Storm, D. (2002). Themed flagship brand stores in the new millennium: Theory, practice, prospects. Journal of Retailing, 78(1), 17-29. doi: 10.1016/s0022-4359(01)00063-x 
Krippendorff, K. (2004). Content Analysis: An Introduction to Its Methodology (2nd ed.). Thousand Oaks, CA: SAGE.

Lee, Y., Kim, S., Seock, Y. K., \& Cho, Y. (2009). Tourists' attitudes towards textiles and apparel-related cultural products: A cross-cultural marketing study. Tourism Management, 30(5), 724-732. doi: 10.1016/j.tourman.2008.10.007

Littrell, M. A., Anderson, L. F., \& Brown, P. J. (1993). What makes a craft souvenir authentic? Annals of Tourism Research, 20(1), 197-215. doi: 10.1016/01607383(93)90118-m

Lovelock, C. H. (1996). Services Marketing (3rd ed.). Englewood Cliffs, NJ: Prentice Hall.

MacCannell, D. (1976). The Tourist: A New Theory of the Leisure Class. New York, NY: Schocken.

Mano, H., \& Oliver, R. L. (1993). Assessing the dimensionality and structure of the consumption experience: Evaluation, feeling, and satisfaction. Journal of Consumer Research, 20(3), 451-466.

Mathwick, C., Malhotra, N. K., \& Rigdon, E. (2001). Experiential value: Conceptualization, measurement and application in the catalog and Internet shopping environment. Journal of Retailing, 77(1), 39-56.

Mathwick, C., Malhotra, N. K., \& Rigdon, E. (2002). The effect of dynamic retail experiences on experiential perceptions of value: An internet and catalog comparison. Journal of Retailing, 78(1), 51-60. doi: 10.1016/s0022-4359(01)00066-5

Mattsson, J. (1991). Better Business by the ABC of Values. Lund, Sweden: Studentlitteratur.

Mo, C. M., Howard, D. R., \& Havitz, M. E. (1993). Testing an international tourist role typology. Annals of Tourism Research, 20(2), 319-335. doi: 10.1016/01607383(93)90058-b

Morgan, M., Elbe, J., \& de Esteban Curiel, J. (2009). Has the experience economy arrived? The views of destination managers in three visitor-dependent areas. Progress in Tourism and Hospitality Research, 11(2), 201-216.

Moscardo, G., Ballantyne, R., \& Hughes, K. (2007). Designing interpretive signs: Principles in practice: Fulcrum Publishing.

Mossberg, L. (2007). A marketing approach to the tourist experience. Scandinavian Journal of Hospitality \& Tourism, 7(1), 59-74. doi: 10.1080/15022250701231915

Mossberg, L. (2008). Extraordinary experiences through storytelling. Scandinavian Journal of Hospitality and Tourism, 8(3), 195-210.

Murphy, P. E., Pritchard, M. P., \& Smith, B. (2000). The destination product and its impact on traveller perceptions. Tourism Management, 21(1), 43-52. doi: 10.1016/s02615177(99)00080-1

Naylor, G., Kleiser, S. B., Baker, J., \& Yorkston, E. (2008). Using transformational appeals to enhance the retail experience. Journal of Retailing, 84(1), 49-57. doi: 10.1016/j.jretai.2008.01.001

Nicholls, R. F. (2005). Interactions between Service Customers: Managing On-Site Customer-to-Customer Interactions for Service Advantage. Poznan, Poland: Poznan University of Economics.

Oh, H., Fiore, A. M., \& Jeoung, M. (2007). Measuring experience economy concepts: Tourism applications. Journal of Travel Research, 46(2), 119-132. doi: $10.1177 / 0047287507304039$

Olivia, H. J. (1999). Understanding and measuring tourist destination images. International Journal of Tourism Research, 1(1), 1-15.

Onderwater, L., Richards, G., \& Stam, S. (2000). Why tourists buy textile souvenirs: European evidence. Tourism, Culture and Communication, 2(1), 39-48. 
Ooi, C. S. (2005). A theory of tourism experiences: The management of attention. In T. O'Dell \& P. Billing (Eds.), Experiencescapes: Tourism, culture and economy (pp. 5168). Denmark: Copenhagen Business School Press.

Oswald, A. M., Ram, K., \& Michael, B. (2006). Lasting customer loyalty: A total customer experience approach. Journal of Consumer Marketing, 23(7), 397-405. doi: 10.1108/07363760610712939

Pearce, P. L., \& Wu, M.-Y. (2014). Tourists' Evaluation of a Romantic Themed Attraction: Expressive and Instrumental Issues. Journal of Travel Research. doi: $10.1177 / 0047287514538838$

Pine, B. J., \& Gilmore, J. H. (1998). Welcome to the experience economy. Harvard Business Review, 76(4), 97-105.

Pine, B. J., \& Gilmore, J. H. (1999). The Experience Economy: Work is Theatre \& Every Business a Stage. Boston, MA: Harvard Business School Press.

Price, L. L., Arnould, E. J., \& Tierney, P. (1995). Going to extremes: Managing service encounters and assessing provider performance. Journal of Marketing, 59(2), 83-97.

Pullman, M. E., \& Gross, M. A. (2004). Ability of experience design elements to elicit emotions and loyalty behaviors. Decision Sciences, 35(3), 551-578.

Richards, G. (2001). The experience industry and the creation of attractions. In G. Richards (Ed.), Cultural Attractions and European Tourism (pp. 55-69). Oxon, UK: CABI.

Richards, L. (2009). Handling Qualitative Data: A Practical Guide (2nd ed.). London, UK: SAGE.

Ritchie, J. R. B., Tung, V. W. S., \& Ritchie, R. J. B. (2011). Tourism experience management research: Emergence, evolution and future directions. International Journal of Contemporary Hospitality Management, 23(4), 419-438. doi: 10.1108/09596111111129968

Rosenbaum, M. S. (2006). Exploring the social supportive role of third places in consumers' lives. Journal of Service Research, 9(1), 59-72. doi: 10.1177/1094670506289530

Ross, G. F. (1998). The Psychology of Tourism (Vol. 1). Melbourne, Australia: Hospitality Press.

Ruan, Y., \& Shao, Y. (1996). Characteristics and protection of water towns in Jiangnan area. Tongji University Journal (Humanities and Social Science Section), 7(1), 21-28.

Sandström, S., Edvardsson, B., Kristensson, P., \& Magnusson, P. (2008). Value in use through service experience. Managing Service Quality, 18(2), 112-126.

Scapp, R., \& Seitz, B. (1998). Introduction. In R. Scapp \& B. Seitz (Eds.), Eating Culture (pp. 1-10). Albany, NY: State Universtiy of New York.

Schutz, A. (1954). Concept and theory formation in the social sciences. Journal of philosophy, 51(9), 257-273.

Shaw, C., \& Ivens, J. (2002). Building Great Customer Experiences. New York, NY: Palgrave.

Sheth, J. N., Newman, B. I., \& Gross, B. L. (1991a). Consumption Values and Market Choices: Theory and Applications. Cincinnati, OH: South-Western Publishing.

Sheth, J. N., Newman, B. I., \& Gross, B. L. (1991b). Why we buy what we buy: A theory of consumption values. Journal of Business Research, 22, 159-170.

Silpakit, P., \& Fisk, R. (1985). Participatizing the service process: A theoretical framework. In T. M. Bloch, G. D. Upah \& V. A. Zeithaml (Eds.), Services Marketing in a Changing Environment (pp. 117-121). Chicago, IL: American Marketing.

Sinha, I., \& DeSarbo, W. S. (1998). An integrated approach toward the spatial modeling of perceived customer value. Journal of Marketing Research, 35(2), 236-249. 
Slåtten, T., Mehmetoglu, M., Svensson, G., \& Sværi, S. (2009). Atmospheric experiences that emotionally touch customers: A case study from a winter park. Managing Service Quality, 19(6), 721-746.

Smith, J. B., \& Colgate, M. (2007). Customer value creation: A practical framework. Journal of Marketing Theory and Practice, 15(1), 7-23.

Smith, S. L. J. (1994). The tourism product. Annals of Tourism Research, 21(3), 582-595. doi: 10.1016/0160-7383(94)90121-x

Squire, S. J. (1994). Gender and tourist experiences: Assessing women's shared meanings for Beatrix Potter. Leisure Studies, 13(3), 195-209.

Sweeney, J. C., \& Soutar, G. N. (2001). Consumer perceived value: The development of a multiple item scale. Journal of Retailing, 77(2), 203-220. doi: 10.1016/s00224359(01)00041-0

Timothy, D. J., \& Butler, R. W. (1995). Cross-boder shopping: A North American perspective. Annals of Tourism Research, 22(1), 16-34. doi: 10.1016/01607383(94)00052-t

Trauer, B., \& Ryan, C. (2005). Destination image, romance and place experience - An application of intimacy theory in tourism. Tourism Management, 26(4), 481-491. doi: 10.1016/j.tourman.2004.02.014

Valentine, G. (1999). Food, leisure and the negotiation of sexual relations. In D. Crouch (Ed.), Leisure/Tourism Geographies: Practices and Geographical Knowledge (pp. 164-180). London, UK: Routledge.

Van Limberg, B. (2009). The anatomy of a digital storytelling system: The architecture. Information Technology \& Tourism, 11(1), 31-42.

Wang, Y., Lo, H. P., Chi, R., \& Yang, Y. (2004). An integrated framework for customer value and customer-relationship-management performance: A customer-based perspective from China. Managing Service Quality, 14(2/3), 169-182.

Woodall, T. (2003). Conceptualising 'value for the customer': An attributional, structural and dispositional analysis. Academy of Marketing Science Review, 2003, 1-42.

Woodruff, R. B. (1997). Customer value: The next source for competitive advantage. Academy of Marketing Science, 25(2), 139-153.

Xu, H., Cui, Q., Ballantyne, R., \& Packer, J. (2013). Effective environmental interpretation at Chinese natural attractions: The need for an aesthetic approach. Journal of Sustainable Tourism, 21(1), 117-133.

Yaghmour, S., \& Scott, N. (2009). Inter-organizational collaboration characteristics and outcomes: A case study of the Jeddah Festival. Journal of Policy Research in Tourism, Leisure and Events, 1(2), 115-130. doi: 10.1080/19407960902992175

Zeithaml, V. A. (1988). Consumer perceptions of price, quality, and value: A means-end model and synthesis of evidence. Journal of Marketing, 52(3), 2-22.

Zeithaml, V. A., Bitner, M. J., \& Gremler, D. D. (2008). Services Marketing (5th ed.). New York, NY: McGraw-Hill.

Zomerdijk, L. G., \& Voss, C. A. (2010). Service design for experience-centric services. Journal of Service Research, 13(1), 67-82. doi: 10.1177/1094670509351960 
GAO, L., SCOTT, N., \& DING, P. (2016). THEME, ATTRIBUTES AND VALUE OF A VISIT TO ZHOUZHUANG, CHINA. JOURNAL; OF DESTINATION MARKETING AND MANAGEMENT. ACCEPTED JANUARY 2016

Corresponding author

Lihua Gao, School of Social Science, Soochow University

Level 4, Building 1005, Dushu Lake Campus, Soochow University, Suzhou, 215123, P. R .China

Email: lihua-gao@hotmail.com

Phone: 0086-18013101618

Fax: 0086-512-65123387

Co-authors:

Noel Scott, Griffith Institute for Tourism, Griffith University

Building (G27), Room 3.12, Gold Coast campus, Griffith University, QLD 4222, Australia Email: noel.scott@griffith.edu.au

Peiyi Ding, Tourism Confucius Institute, Griffith University

Gold Coast Campus, Griffith University, QLD, 4222, Australia

Email: p.ding@griffith.edu.au 